\title{
Nature of the Major Inorganic Ions Concentrated during Growth of Bacillus amyloliquefaciens
}

\author{
By G. COLEMAN \\ Department of Biochemistry, Nottingham University Medical School, \\ Nottingham $N_{7} 2 R D$
}

(Received 26 March 1974; revised I May 1974)

\begin{abstract}
SUMMARY
Bacillus amyloliquefaciens took up inorganic ions from the medium during growth. Their distribution between the cytoplasmic fraction and the envelope varied from almost exclusively cytoplasmic to completely envelope-bound in the order: $\mathrm{K}^{+}, 4 \cdot 7 \% ; \mathrm{Mg}^{2+}, 32 \cdot 0 \% ;$ phosphate, $60 \cdot 2 \% ; \mathrm{Na}^{+}, 80 \cdot 4 \% ; \mathrm{Ca}^{2+}, 96 \cdot \mathrm{I} \%$; and $\mathrm{Cl}^{-}, 100 \%$ envelope-bound. During the transition from minimum to maximum rate of extracellular enzyme secretion the intracellular levels of the following ions were unchanged at $\mathrm{K}^{+}, 583 \pm 54 \mathrm{mM}$; phosphate, $459 \pm 40 \mathrm{~mm} ; \mathrm{Mg}^{2+}, 56 \pm 6 \mathrm{~mm}$; and $\mathrm{Na}^{+}, 22 \pm 4 \mathrm{mM}$.
\end{abstract}

\section{INTRODUCTION}

Secretion of extracellular enzymes by Bacillus amyloliquefaciens occurs almost exclusively in the post-exponential phase of the growth cycle and Coleman (1969a) studied the effect of ionic environment on the distribution of polyribosomes between the soluble and membrane components of cell-free preparations. Subsequently, a comparison was made of the abilities of free and membrane-bound polyribosomes to incorporate amino acids into protein (Coleman, $1969 b$ ) and of the distribution of the $\alpha$-amylase-forming ability between the membrane and soluble fractions of a cell-free system (Coleman, 1970). The results suggested that the distribution of enzyme-forming ability, between the membrane and soluble fractions of cell-free preparations of post-exponential phase bacteria, could be altered by changing the ionic environment. It seemed important therefore to determine the nature of the ionic environment within the bacteria; that is, to determine the actual concentrations of inorganic ions (most particularly $\mathrm{K}^{+}$and $\mathrm{Mg}^{2+}$ ) in the cytoplasm rather than their relative proportions in samples of dried bacteria. This would involve correcting for ions associated with the envelope and which do not contribute to the cytoplasmic concentrations (Tempest, 1969). The results presented here show the uptake of various ions from the medium during the growth of $B$. amyloliquefaciens and how they are distributed between the cytoplasm and envelope. By determining intracellular water contents, a measure of the concentrations of ions in the cytoplasm has been obtained.

\section{METHODS}

Organism and culture. The aerobic, spore-forming B. amyloliquefaciens strain $\mathrm{T}$ (Welker \& Campbell, 1967) was grown in a I \% maltose-0.5\% casein hydrolysate complex medium (Coleman, 1969a).

Preparation of whole cell samples for assay. A series of up to twenty $50 \mathrm{ml}$ cultures, in $250 \mathrm{ml}$ conical flasks, was incubated at $30^{\circ} \mathrm{C}$ for $18 \mathrm{~h}$, pooled and redistributed in the original flasks to give identical cultures. At each sampling time two cultures were taken, mixed, and $5 \mathrm{ml}$ samples retained for bacterial density and $\alpha$-amylase determination. The 
remaining $2 \times 40 \mathrm{ml}$ volumes were transferred to tared $50 \mathrm{ml}$ centrifuge tubes, $0 \cdot \mathrm{I} \mathrm{ml}{ }^{14} \mathrm{C}$ labelled inulin (Io $\mu \mathrm{Ci} / \mathrm{ml}$ ) being added to one of them. The two cultures were then centrifuged at $6000 \mathrm{~g}$ for $3 \mathrm{~min}$ at $30^{\circ} \mathrm{C}$, after which the pellets were drained and the supernatant fractions retained. The tubes containing the drained pellets were reweighed to determine the wet weights of the pellets, which were then resuspended in ion-free water, made up to $5 \mathrm{ml}$ in graduated, stoppered tubes and the resulting preparations retained for assay.

Preparation of bacterial envelope samples for assay. Samples $(2 \times 40 \mathrm{ml})$ of culture were taken in $50 \mathrm{ml}$ centrifuge tubes and the bacterial pellets isolated by centrifuging at $6000 \mathrm{~g}$ for $3 \mathrm{~min}$. The packed bacteria were resuspended to $10 \mathrm{ml}$ in supernatant fraction and disrupted either by treatment with an ultrasonic disintegrator ( $100 \mathrm{~W}, 20 \mathrm{kHz}$; M.S.E. Ltd, Crawley, Sussex) for $2 \times 5 \mathrm{~min}$, or by three passages through a French pressure cell ('Aminco', American Instrument Co. Inc., Silver Springs, Maryland, U.S.A.), at a temperature as close to $30{ }^{\circ} \mathrm{C}$ as possible in each case. Microscopic examination showed the two preparations were similar, no intact bacteria being detected in either. A sample $(5 . \mathrm{ml})$ of each of the disrupted preparations was then resuspended in supernatant to $20 \mathrm{ml}$ and the resulting suspension processed as described above for the preparation of whole bacterial samples for assay. Determination of extracellular space using ${ }^{14} \mathrm{C}$-labelled inulin was not necessary as this is given by the difference between wet and dry weights of the disrupted bacterial pellets.

Determination of extracellular space of intact bacterial pellets. A sample $(0.5 \mathrm{ml})$ of the suspension of bacteria from the culture containing ${ }^{14} \mathrm{C}$-labelled inulin, and $0.5 \mathrm{ml}$ of the supernatant fraction from the same centrifuged culture were each added to a counting vial containing $5 \mathrm{ml}$ of scintillation fluid [5.5 g 2,5-diphenyloxazol (PPO) dissolved in $\mathrm{I} 1$ of a 2: I mixture of xylene and Triton X-IOo]. The radioactivity was determined using a Packard liquid scintillation spectrometer. The volume of supernatant fraction or extracellular space in the centrifuged pellet from a $40 \mathrm{ml}$ culture was calculated from the results.

Determination of total moisture content of bacterial pellets. A sample of resuspended bacterial pellet $(2.5$ to $4.5 \mathrm{ml})$ was transferred to a weighed beaker together with an equal volume of acetone. The preparation was evaporated to dryness using a $60 \mathrm{~W}$ i.r. lamp and dried to constant weight at $110{ }^{\circ} \mathrm{C}$ to give the dry weight of the centrifuged bacterial pellet. This, when subtracted from the wet weight, gave the moisture content - the sum of the intracellular water plus that which occupies the extracellular space.

Intracellular water content of bacteria in centrifuged pellets. This was obtained by subtracting the amount of water occupying the extracellular space from the total moisture content of bacterial pellets.

Cation determination. Samples $(2.5 \mathrm{ml})$ of centrifuged bacterial pellet from $40 \mathrm{ml}$ batches of culture were resuspended in ion-free water to $5 \mathrm{ml}$. The corresponding supernatant fractions were placed in graduated, stoppered tubes with $0.5 \mathrm{ml}$ concentrated nitric acid and made up to $5 \mathrm{ml}$. These preparations were allowed to stand overnight, after which they were suitably diluted and their $\mathrm{Mg}^{2+}, \mathrm{Ca}^{2+}, \mathrm{Na}^{+}$and $\mathrm{K}^{+}$contents determined by means of a Unicam SP 90 A series 2 Atomic Absorption Spectrometer. From the results obtained and data for the intra- and extracellular space in the centrifuged pellets, the whole cell-bound and envelope-bound ions were calculated.

Chloride determination. Chloride was determined in the samples used for cation assay by potentiometric titration as described by Sanderson (1952).

Phosphorus determination. Phosphate was estimated as phosphorus in the dried bacterial pellets remaining from the determination of moisture contents and in the corresponding supernatant fractions by the method of King (1932).

$\alpha$-Amylase assay. The method of Coleman \& Elliott (1962) was used. 
Table I. The envelope-bound inorganic ions and intracellular ion concentrations in B. amyloliquefaciens

The bacteria from a $24 \mathrm{~h}$ culture ( $40 \mathrm{ml}$ batches), disrupted by means of a French pressure cell, were processed as described in Methods.

\begin{tabular}{|c|c|c|c|c|}
\hline Ion & $\begin{array}{l}\text { Whole cell } \\
\text { associated } \\
(\mu \mathrm{g})\end{array}$ & $\begin{array}{l}\text { Envelope-bound } \\
(\mu \mathrm{g})\end{array}$ & $\begin{array}{l}\text { Intracellular } \\
(\mu \mathrm{g})\end{array}$ & $\begin{array}{l}\text { Concn. of free } \\
\text { intracellular ion } \\
\text { (mM) }\end{array}$ \\
\hline $\mathbf{M g}^{2+}$ & $77 \cdot 15$ & $23 \cdot 30$ & $53 \cdot 85$ & 46 \\
\hline $\mathbf{K}^{+}$ & $1011 \cdot 5$ & $49 \cdot 27$ & $962 \cdot 2$ & $5 \mathrm{I} 4$ \\
\hline $\mathrm{Na}^{+}$ & 97 & 80 & 17 & I5 \\
\hline $\mathrm{Ca}^{2+}$ & $5 \cdot 37$ & $4 \cdot 73$ & 0.64 & 0.33 \\
\hline $\mathrm{Cl}^{-}$ & $44 \cdot 4$ & $42 \cdot 6$ & I. 8 & $1 \cdot 0$ \\
\hline Phosphate P & $1530^{\circ}$ & 903 & 627 & 422 \\
\hline
\end{tabular}

\section{RESULTS}

Measurement of whole cell and envelope-bound inorganic ions

To determine the intracellular concentration, measurements were made of the ions bound to envelopes separated from bacteria quantitatively disrupted in their culture medium and these values were subtracted from those for ions associated with the whole bacteria. Similar values for ion concentrations in late exponential phase bacteria were obtained by disrupting them with either the French pressure cell (Table I) or an ultrasonic disintegrator.

\section{Progress of uptake of ions during bacterial growth}

Late exponential phase bacteria contain little or no intracellular $\mathrm{Ca}^{2+}$ or $\mathrm{Cl}^{-}$, although appreciable amounts of these ions are associated with whole bacteria (Table I). The intracellular concentrations of $\mathrm{Mg}^{2+}, \mathrm{K}^{+}, \mathrm{Na}^{+}$and phosphate were much higher. During the incubation period the uptake of cations into envelope and soluble fractions increased whilst the uptake of phosphate diminished at $26 \mathrm{~h}$, reflecting the end of exponential growth rather than a limitation in its supply (Fig. I). At the end of the experiment only $6.5 \%$ of the phosphate originally present in the medium had been taken up by the bacteria (Table 2 ).

\section{Intracellular ion concentrations during the growth cycle}

The intracellular concentrations of $\mathrm{Mg}^{2+}, \mathrm{K}^{+}, \mathrm{Na}^{+}$and phosphate in relation to bacterial growth and the secretion of extracellular $\alpha$-amylase are shown in Fig. 2. The concentrations of $\mathrm{Mg}^{2+}, \mathrm{K}^{+}$and phosphate did not change by more than $\pm 10 \%$ during the period of the experiment. Within these limits, $\mathrm{K}^{+}$concentration showed a random variation whilst $\mathbf{M g}^{2+}$ and phosphate concentrations tended to fall after the end of exponential growth. The level of $\mathrm{Na}^{+}$increased during the transition to the post-exponential state.

\section{DISCUSSION}

An attempt was made to measure the concentrations of ions within the cytoplasm of a bacterium throughout its growth cycle. The measurement of total ions associated with the bacterial cell was made on rapidly harvested samples subjected to the minimum of disturbance with no change in ionic environment. An element of uncertainty was introduced only in determining the envelope-bound ions owing to the difficulty of avoiding changing ionic equilibria during the preparation of samples for assay. It was decided that the closest approxi- 

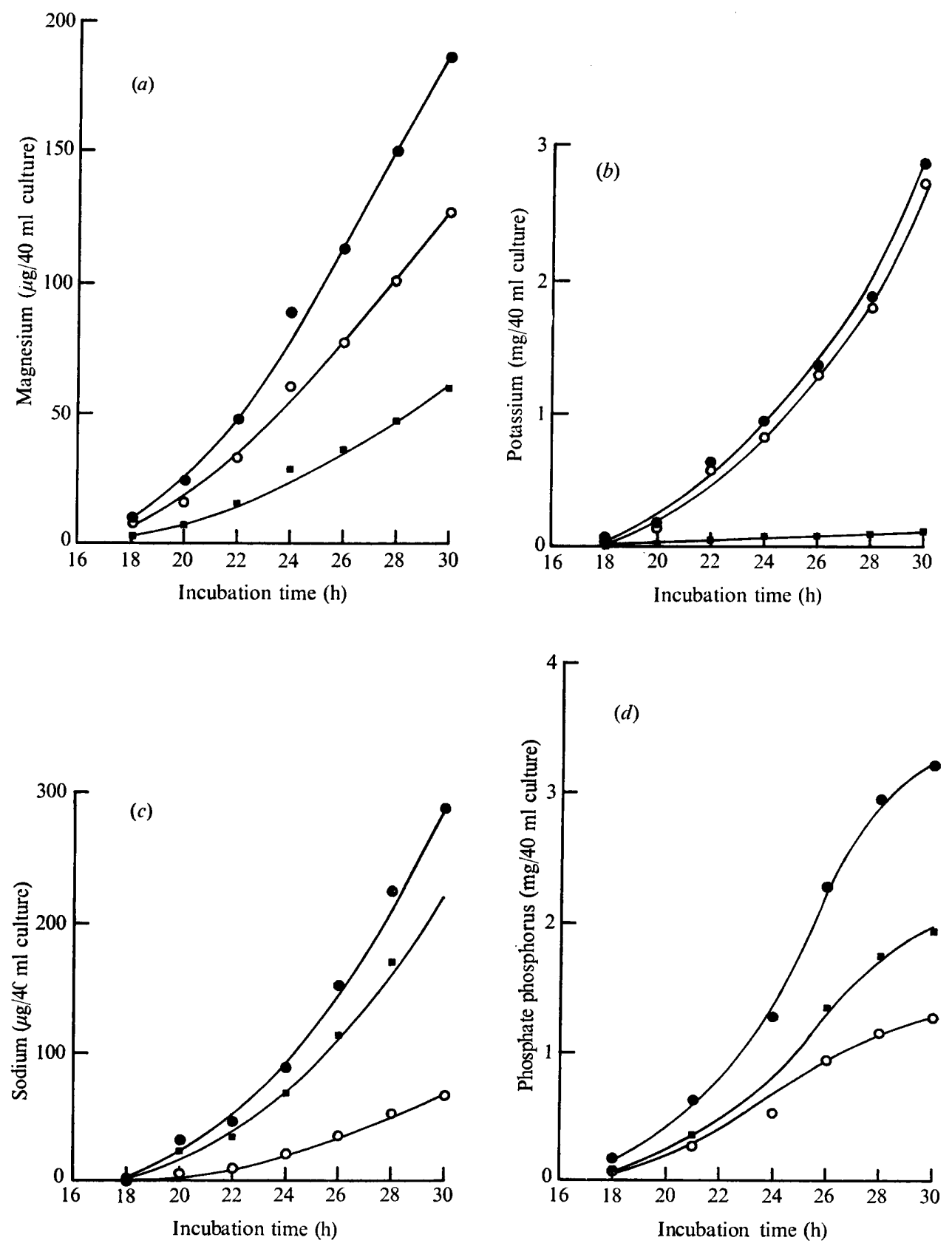

Fig. I. The uptake of inorganic ions (O) from the growth medium by B. amyloliquefaciens and their distribution between the cytoplasm (O) and the bacterial envelope ( $(\mathbf{})$. (a) $\mathrm{Mg}^{2+} ;(b) \mathrm{K}^{+} ;(c) \mathrm{Na}^{+}$; (d) phosphate as phosphorus. 
Table 2. The uptake of inorganic ions from the growth medium by the bacteria after $a 30$ incubation

\begin{tabular}{|c|c|c|c|}
\hline Ion & $\begin{array}{l}\text { Initial ion content } \\
\text { of medium } \\
\text { ( } \mathrm{mg} / 40 \mathrm{ml} \text { culture) }\end{array}$ & $\begin{array}{l}\text { Final ion content } \\
\text { of bacteria } \\
\text { ( } \mathrm{mg} / 40 \mathrm{ml} \text { culture) }\end{array}$ & $\begin{array}{c}\text { Ion uptake by } \\
\text { bacteria } \\
(\%)\end{array}$ \\
\hline & $8 \cdot 180$ & 0.112 & $1 \cdot 4$ \\
\hline $\mathrm{PO}_{4}{ }^{3-}$ (as $\mathrm{P}$ ) & $49 \cdot 6$ & $3 \cdot 2$ & $6 \cdot 5$ \\
\hline $\mathrm{Na}^{+}$ & $12 \cdot 88$ & 0.287 & $2 \cdot 2$ \\
\hline $\mathrm{Ca}^{2+}$ & 0.16 & 0.017 & 10.9 \\
\hline $\mathbf{M g}^{2+}$ & 0.97 & 0.188 & $19 \cdot 3$ \\
\hline $\mathbf{K}^{+}$ & $7 \cdot 19$ & $2 \cdot 87$ & $39 \cdot 9$ \\
\hline
\end{tabular}

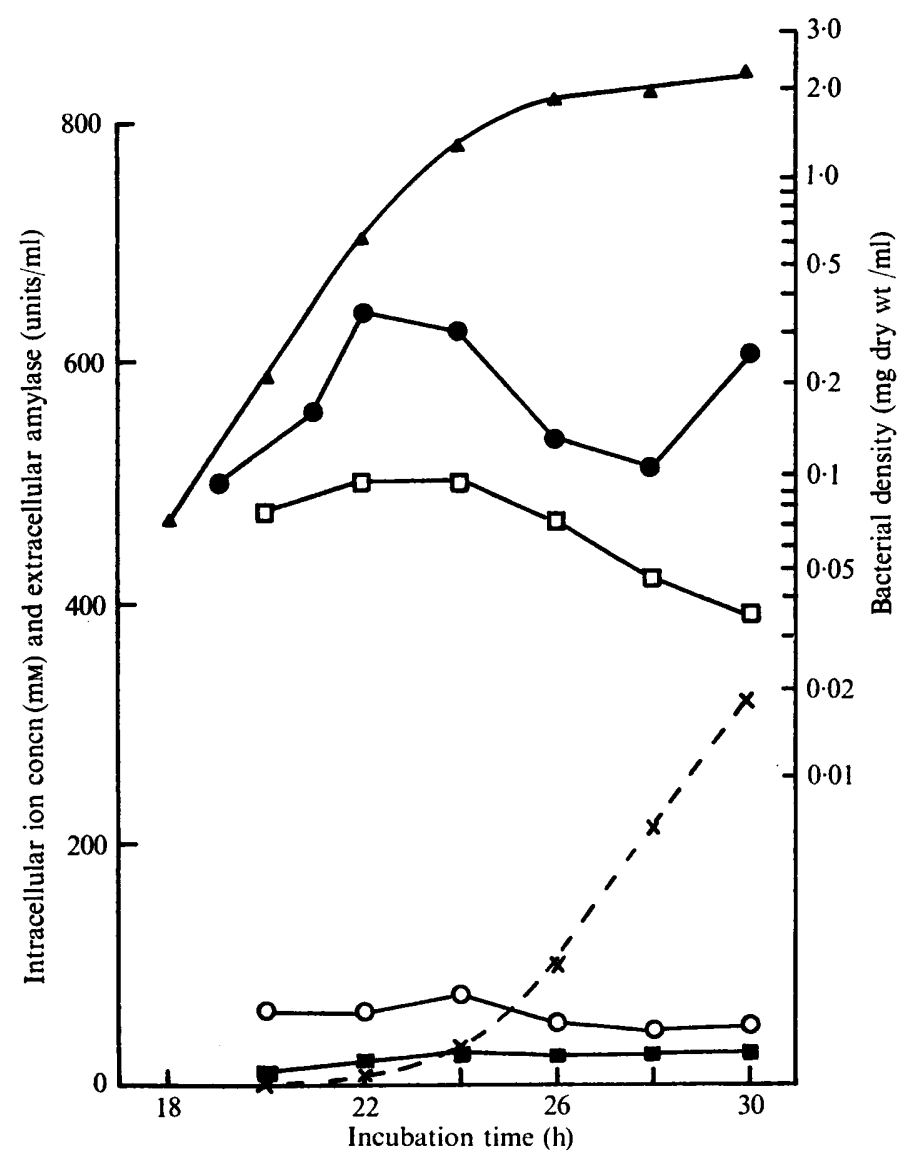

Fig. 2. The intracellular concentrations of $\mathrm{Mg}^{2+}(O), \mathrm{K}^{+}(\boldsymbol{O}), \mathrm{Na}^{+}(\boldsymbol{\square})$ and phosphate as phosphorus $(\square)$ in relation to increase in bacterial density $(\Delta)$ and extracellular $\alpha$-amylase secretion $(\times)$.

mation might be achieved by mechanically disrupting bacteria in their media in order to liberate intracellular constituents from the envelope. This assumes that the nature of the attachments to the inside of the membrane is not altered to an extent that would significantly affect the total ion attachment to the whole envelope; it is unlikely that the ionic attachments to the outside of the envelope fragments would be disturbed since their ionic environment is virtually unchanged. 
There is no detectable $\mathrm{Ca}^{2+}$ or $\mathrm{Cl}^{-}$within the bacteria, these ions being entirely envelopebound as is $80 \%$ of the total $\mathrm{Na}^{+}$. However, nearly all the $\mathrm{K}^{+}$and two-thirds of the $\mathrm{Mg}^{2+}$ and phosphate are intracellular, although these ions cannot be regarded as 'free' since most of the cations are associated with the phosphate which is in macromolecular structures, such as DNA and ribosomes, principally the latter. The molar ratios of cytoplasmic $\mathrm{Mg}^{2+}: \mathrm{K}^{++}: \mathrm{P}$ is $\mathrm{I}: \mathrm{I} 0 \cdot 5: 8$, compared with values of $\mathrm{I}: 8: 15$ for whole bacteria.

Coleman (1969a) observed that lowering the $\mathrm{K}^{+} / \mathrm{Mg}^{2+}$ ratio in cell-free preparations of $B$. amyloliquefaciens increased the proportion of membrane-bound ribosomal material. The $\alpha$-amylase-forming system is concentrated in the membrane fraction of post-exponential phase bacteria (Coleman, 1970). It follows that during the change from exponential to post-exponential state, when exoenzyme secretion rises, a lowered $\mathrm{K}^{+}: \mathrm{Mg}^{2+}$ ratio might be expected. However, since the results show no significant change in the $\mathrm{K}^{+}: \mathrm{Mg}^{2+}$ ratio of 10.5 during the transition to the post-exponential phase, simple shifts in intracellular ionic equilibria are not factors important in the regulation of extracellular enzyme secretion.

\section{REFERENCES}

Coleman, G. (1969a). Effect of potassium ions on the attachment of polyribosomes to the membranes in lysates of exponential-phase cells of Bacillus amyloliquefaciens. Biochemical Journal 112, 533-539.

Coleman, G. $(1969 b)$. Comparison of the abilities of free and membrane-bound polyribosomes isolated from exponential-phase cells of Bacillus amyloliquefaciens to incorporate amino acids into protein. Biochemical Journal 115, 863-864.

Coleman, G. (1970). The distribution of $\alpha$-amylase-forming ability between the membrane and soluble fractions of a cell-free preparation of Bacillus amyloliquefaciens. Biochemical Journal 116, 763-765.

Coleman, G. \& Elliotr, W. H. (1962). Studies on $\alpha$-amylase formation by Bacillus subtilis. Biochemical Journal 83, 256-263.

KING, E. J. (I932). The colorimetric determination of phosphorus. Biochemical Journal 26, $292-297$.

SANDERSON, P. H. (1952). Potentiometric determination of chloride in biological fluids. Biochemical Journal 52, 502-505.

TEMPEST, D. W. (1969). Quantitative relationships between inorganic cations and anionic polymers in growing bacteria. Symposia of the Society for General Microbiology r9, 87-I I I.

Welker, N. E. \& CAMPBell, L. L. (1967). Comparison of the $\alpha$-amylase of Bacillus subtilis and Bacillus amyloliquefaciens. Journal of Bacteriology 94, I I 3 I-I 135. 